\title{
SIMULATION OF A MOTOR VEHICLE'S MOTION ON THE BASIS OF A TURNING WITH THE STEERING WHEEL RELEASE
}

\author{
Symulacja ruchu samochodu w oparciu o skręt ze \\ zwolnieniem koła kierownicy
}

\begin{abstract}
In this paper, the selected phenomena related to a motor vehicle's motion have been considered based on a computer simulation in MSC Adams/Car. The vehicle's model performed a turning maneuver with the steering wheel release under different road conditions.

All simulations have been performed based on the sports two-seater vehicle's model, at the initial speed of $70 \mathrm{~km} / \mathrm{h}$ on the flat and randomly uneven road. This enabled us to observe the selected phenomena along the road long enough to relate them to different aspects of road traffic safety in unusual situations. For uneven road, the same profiles were assumed for the left and the right wheel of the vehicle, with two coefficient values determining the maximum height of these irregularities.
\end{abstract}

Keywords: vehicle dynamics, turning maneuver, lateral motion

Streszczenie: W artykule rozważono wybrane zjawiska zwiąane z ruchem samochodu na podstawie symulacji komputerowej w programie MSC Adams/Car. Model pojazdu wykonat manewr skrętu ze zwolnieniem koła kierownicy przy różnych warunkach drogowych.

Wszystkie symulacje wykonano w oparciu o model pojazdu sportowego, przy prędkości początkowej równej $70 \mathrm{~km} / \mathrm{h}$ na płaskiej i losowo nierównej drodze. Umożliwiło to obserwacje wybranych zjawisk na drodze na tyle dtugiej, aby odnieść je do różnych aspektów bezpieczeństwa ruchu drogowego w sytuacjach nietypowych. Dla drogi nierównej przyjęto podobne profile dla lewego $i$ prawego koła pojazdu z dwiema wartościami współczynnika określającego maksymalna wysokość tych nierówności.

Słowa kluczowe: dynamika samochodu, manewr skrętu, ruch poprzeczny 


\section{Introduction}

The lateral motion of a motor vehicle can sometimes pose a threat to the road traffic safety, especially when such motion cannot be controlled or occurs when the road conditions are difficult, e.g. wet or icy surface, bad weather or strong wind gusts. Another factor that may influence the vehicle's response is the road irregularities described usually as a stochastic process due to their randomness. Road safety requires research in several areas, one of which is the dynamics of motor vehicles. Part of research on road traffic safety is related to steering because it is the most important maneuver enabling changes in the direction of motion. This problem has been widely addressed in many papers, e.g. [1].

The aim of this manuscript is to present the selected aspects of motor vehicle dynamics based on simulations of a turning with a steering wheel release performed in MSC Adams/Car environment. As for the adopted maneuver, different road conditions have been adopted along with the selected loading configurations. This was made in order to perform an exemplary analysis of a motor vehicle in the specific road conditions while in turn.

The research on road traffic safety comprises such problems as, e.g. the normal reaction forces acting on the wheels, which is directly related to both the suspension and the cooperation between the wheels and the road and has so far been undertaken, e.g. in [1,6].

The presented paper is only an example of a variety of different problems related to the influence of road conditions on road traffic safety. Some areas reach even beyond that proving that the scope of research on the transport means is much wider. For example, [5] has been devoted to the railway motion while in [7] the selected telematics problems in vehicles have been considered. For example, in [3], a broader spectrum of simulations has been considered.

The maneuver adopted in this paper may be considered as unreal, but in order to reflect the dangerous situation, it fits perfectly, as it seems reliable to analyze the vehicle's response to the acting disturbances in a situation when a driver loses control while taking a turn.

\section{Simulation assumptions}

A double seater vehicle's model has been used here (its body is shown in figs. 1 and 2 ) as in some previous papers written by the author, e.g. [5, 8]. In these papers, however, it has been treated differently, as presented in this chapter. Also, in [8], the attention has been paid to the turning with the steering wheel release as well, but only for the first $5 \mathrm{~s}$ of the maneuver and for the initial velocity was assumed to be $50 \mathrm{~km} / \mathrm{h}$ with $500 \mathrm{~m}$ turning radius. Here, on the contrary, some important parameters have been altered in order to provide different simulation conditions reflecting different traffic situations.

For the purpose of further analysis, some essential assumptions have been made. First, the mass of the vehicle's body has been increased from $995 \mathrm{~kg}$ to $1155 \mathrm{~kg}$, according to 
figs. 1 and 2. The mass of the driver has been assumed to be $80 \mathrm{~kg}$, the passenger $-60 \mathrm{~kg}$ and the baggage $-20 \mathrm{~kg}$, as in [8].

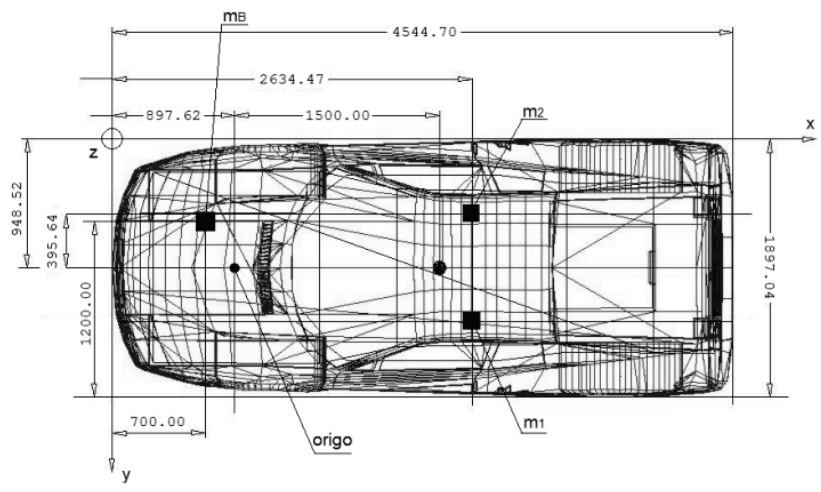

Fig. 1. Location of the masses loading the vehicle body along with the 'origo' point - plan view [13]

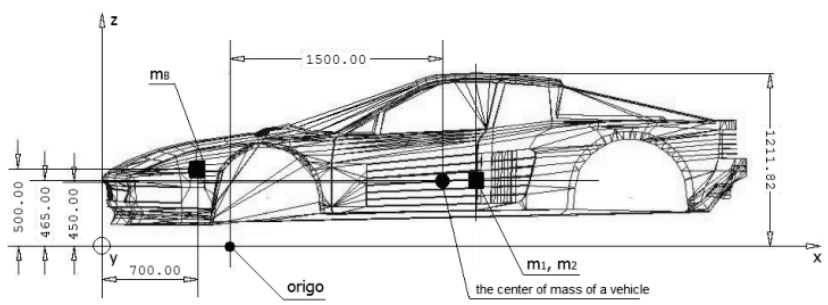

Fig. 2. Location of the masses of the vehicle body along with the 'origo' point - side view [13]

The mass - inertia parameters of the vehicle's body and the whole vehicle have been presented in table 1 before and after loading with the masses representing the driver, the passenger and the baggage. These values have been determined in relation to the axes passing through the 'origo' point, which is the origin of a coordinate system located on the ground but moving along with the vehicle's model while performing the simulations [5].

The most significant changes were noticed in case of the moments of inertia relative to the lateral and vertical axes of the adopted coordinate system with the origin at the 'origo' point. On the contrary, the moments of deviation did not change to such a noticeable extent, although the baggage was dislocated versus the longitudinal plane of symmetry of the vehicle which seems more relevant when reflecting the motor vehicle dynamics in the real circumstances.

The vehicle's model used for the simulations was provided with some necessary changes due to the simulation of motion on the randomly uneven road. The tires were switched from standard ones (PAC89) to the FTire (flexible tires) which can cooperate with the random irregularities. Other assumptions include the partial nonlinearity of the vehicle's 
suspension, which has been discussed, e.g. in [5]. The spring was linear, and the damper was nonlinear in a MacPherson column. The vehicle's body was adopted to be rigid because the vehicle's response to the acting disturbances was more important here than the potential deformations of its body.

Table 1

Mass - inertia parameters of the unladen simulated vehicle model

\begin{tabular}{|c|c|c|c|c|}
\hline & \multicolumn{2}{|c|}{ Unladen vehicle } & \multicolumn{2}{|c|}{ Laden vehicle } \\
\hline & vehicle's body & whole vehicle & vehicle's body & whole vehicle \\
\hline mass & $995 \mathrm{~kg}$ & $1528 \mathrm{~kg}$ & $1155 \mathrm{~kg}$ & $1686 \mathrm{~kg}$ \\
\hline $\begin{array}{l}\text { center of mass location } \\
\text { relative to the 'origo' } \\
\text { point }\end{array}$ & $\begin{array}{l}\mathrm{xc}=1.5 \mathrm{~m} \\
\mathrm{yc}=0, \mathrm{zc}=0.45 \mathrm{~m}\end{array}$ & $\begin{array}{l}\mathrm{xc}=1.75 \mathrm{~m} \\
\mathrm{yc}=-0.0014 \mathrm{~m} \\
\mathrm{zc}=0.43 \mathrm{~m}\end{array}$ & $\begin{array}{l}\mathrm{xc}=1.499 \mathrm{~m} \\
\mathrm{yc}=0.007 \mathrm{~m} \\
\mathrm{zc}=0.452 \mathrm{~m}\end{array}$ & $\begin{array}{l}\mathrm{xc}=1.73 \mathrm{~m} \\
\mathrm{yc}=-0.0004 \mathrm{~m} \\
\mathrm{zc}=0.434 \mathrm{~m}\end{array}$ \\
\hline $\begin{array}{l}\text { moment of inertia (Ix) } \\
\text { relative to the } \mathrm{x} \text { axis } \\
\text { passing through the } \\
\text { 'origo' }\end{array}$ & $401 \mathrm{~kg} \cdot \mathrm{m}^{2}$ & $583 \mathrm{~kg} \cdot \mathrm{m}^{2}$ & $436 \mathrm{~kg} \cdot \mathrm{m}^{2}$ & $618 \mathrm{~kg} \cdot \mathrm{m}^{2}$ \\
\hline $\begin{array}{l}\text { moment of inertia (Iy) } \\
\text { relative to the y axis } \\
\text { passing through the } \\
\text { 'origo' }\end{array}$ & $2940 \mathrm{~kg} \cdot \mathrm{m}^{2}$ & $6129 \mathrm{~kg} \cdot \mathrm{m}^{2}$ & $3331 \mathrm{~kg} \cdot \mathrm{m}^{2}$ & $6520 \mathrm{~kg} \cdot \mathrm{m}^{2}$ \\
\hline $\begin{array}{l}\text { moment of inertia (Iz) } \\
\text { relative to the } \mathrm{z} \text { axis } \\
\text { passing through the } \\
\text { 'origo' }\end{array}$ & $2838 \mathrm{~kg} \cdot \mathrm{m}^{2}$ & $6022 \mathrm{~kg} \cdot \mathrm{m}^{2}$ & $3195 \mathrm{~kg} \cdot \mathrm{m}^{2}$ & $6378 \mathrm{~kg} \cdot \mathrm{m}^{2}$ \\
\hline $\begin{array}{l}\text { moment of deviation (Ixy) } \\
\text { relative to the axes } \mathrm{x} \text { and } \\
\text { y passing through the } \\
\text { 'origo' }\end{array}$ & 0 & $-1.9 \mathrm{~kg} \cdot \mathrm{m}^{2}$ & $12.1 \mathrm{~kg} \cdot \mathrm{m}^{2}$ & $10.2 \mathrm{~kg} \cdot \mathrm{m}^{2}$ \\
\hline $\begin{array}{l}\text { moment of deviation (Izx) } \\
\text { relative to the axes } \mathrm{x} \text { and } \\
\mathrm{z} \text { passing through the } \\
\text { 'origo' }\end{array}$ & $671 \mathrm{~kg} \cdot \mathrm{m}^{2}$ & $1160 \mathrm{~kg} \cdot \mathrm{m}^{2}$ & $782 \mathrm{~kg} \cdot \mathrm{m}^{2}$ & $1271 \mathrm{~kg} \cdot \mathrm{m}^{2}$ \\
\hline $\begin{array}{l}\text { moment of deviation (Iyz) } \\
\text { relative to the axes y and } \\
\text { z passing through the } \\
\text { 'origo' }\end{array}$ & 0 & $-1.3 \mathrm{~kg} \cdot \mathrm{m}^{2}$ & $3.6 \mathrm{~kg} \cdot \mathrm{m}^{2}$ & $2.35 \mathrm{~kg} \cdot \mathrm{m}^{2}$ \\
\hline
\end{tabular}

Certain assumptions concerning the road surface (table 2) were made as well. In table 2 the main assumptions regarded the flat or the randomly uneven road, the correlation 
coefficient specifying the similarity of the irregularities for the left and the right wheel (here, $\operatorname{cor}_{r l}=0.8$ ) and the amplitude of those irregularities (here, the intensity was 0.3 for the lower and 0.9 for the higher amplitudes). The almost similar road profiles for the left and the right wheel is only one of the possible attempts toward the discussed problem. The coefficient of adhesion for the dry road was assumed to be 1.0 and for the icy road -0.3 .

As for the random road irregularities, several works have also been devoted to this area, such as e.g. [6]. It seems important from the point of view of application in the simulation packages, which have been used widely over the years and have become popular as time and cost-reducing and, at the same time, provide the acceptable accuracy, especially in the case of the randomly uneven road. Some works have been devoted to using the selected packages in vehicle dynamics, such as Matlab [2, 4]. However, in this paper, the $\mathrm{MSC} /$ Adams package has been used to perform the adopted maneuver.

Table 2

\section{Configurations adopted for the power-off maneuver simulation}

\begin{tabular}{||l|l|l|l|l|l||}
\hline & Road & Surface & Corrl & Intensity & $\mathrm{V}[\mathrm{km} / \mathrm{h}]$ \\
\hline configuration 1 & flat & dry & - & - & 70 \\
\hline configuration 2 & flat & icy & - & - & 70 \\
\hline configuration 3 & uneven & dry & 0.8 & 0.3 & 70 \\
\hline configuration 4 & uneven & dry & 0.8 & 0.9 & 70 \\
\hline configuration 5 & uneven & icy & 0.8 & 0.3 & 70 \\
\hline configuration 6 & uneven & icy & 0.8 & 0.9 & 70 \\
\hline
\end{tabular}

The simulation of the adopted maneuver with a steering wheel release was run at an initial longitudinal velocity equal to $70 \mathrm{~km} / \mathrm{h}$ on 4 th gear. The initial radius of a turn has been set at $2000 \mathrm{~m}$. It is necessary to mention that the driver's reaction was not taken into account due to the main interest in the vehicle's reaction to the external disturbances.

\section{Discussion on the selected results}

Before discussing the certain phenomena of a vehicle's model performing the adopted maneuver, it seems important to notify that the most important difference between the results presented here and the ones discussed in [8] is that both the initial velocity and the turning radius were different. In [8], the radius was $500 \mathrm{~m}$, and the velocity was $50 \mathrm{~km} / \mathrm{h}$. Meanwhile, here, the radius was $2000 \mathrm{~m}$, and the velocity was $70 \mathrm{~km} / \mathrm{h}$. It is obvious that the adopted conditions of motion are only a piece of a broader research, but due to the 
paper's capacity, they will not be discussed here. The most essential was to examine the impact of the road conditions on the movement of the vehicle after the steering wheel release as if a driver lost control of the vehicle.

In fig. 3, the lateral displacement versus the covered distance for configurations 1 and 2 (table 2) has been presented. In the first section of the covered distance on the flat road (about 50m long), the vehicle moved rather smoothly and continued this motion for the rest of the maneuver with minor deviations from the straight line but just for the dry road. On the icy road though, it started to deviate from the initial course more and more and, at the end of the maneuver, the lateral displacement was nearly $2.5 \mathrm{~m}$ in the absolute value. This means that the icy road did affect the desired course of the vehicle which, in this case, should be regarded as the one obtained for configuration 1 .



Fig. 3. Lateral displacement versus the covered distance on the flat road

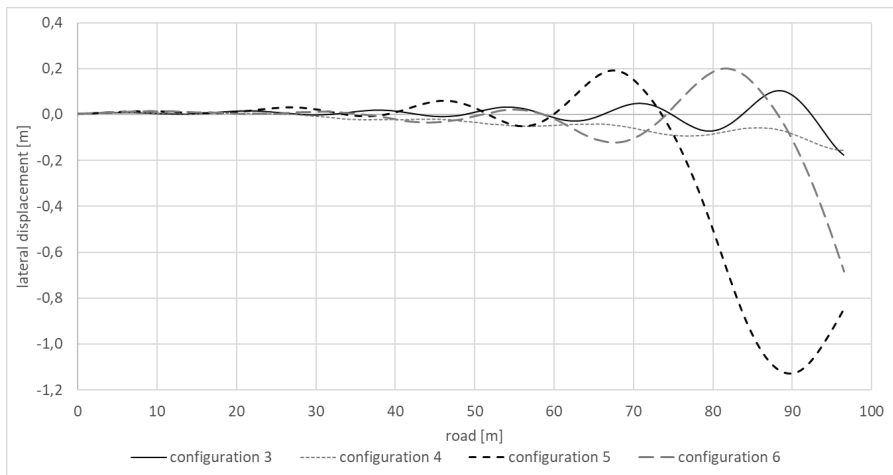

Fig. 4. Lateral displacement versus the covered distance on the randomly uneven road

Similar observations can be made for the motion along the randomly uneven road (fig. 4), although the visible displacements from the desired course occurred at the 40th meter of the covered distance. The maximum deviation (about $1.2 \mathrm{~m}$ in the absolute value) happened on the icy road but with lower amplitudes of the irregularities (configuration 5). 
This let us suppose that the higher irregularities (intensity 0.9 ) with the road profiles similar for the left and the right wheel may decrease the effect of deviation between the desired and the obtained trajectories of motion.

In fig. 5 the lateral velocity versus the covered distance for the flat road and in fig. 6 for the uneven road has been presented. The results presented in fig. 5 reflect the tendency of a vehicle's model to remain on the desired course while moving along the dry road and deviating from it on the icy surface where the lateral velocity increased up to about $3.25 \mathrm{~m} / \mathrm{s}$ in the absolute value, causing the drift effect.

The same occurred for the motion along the randomly uneven road (fig. 6) where the greatest value of the velocity was about $2 \mathrm{~m} / \mathrm{s}$ for the configurations 5 and 6 , i.e. the motion along the uneven and icy road. The smaller velocity resulted in the disturbances caused by the random irregularities on the road. This reflects both increasing this velocity by the icy surface and reducing it by the higher amplitudes of the irregularities at the same time.

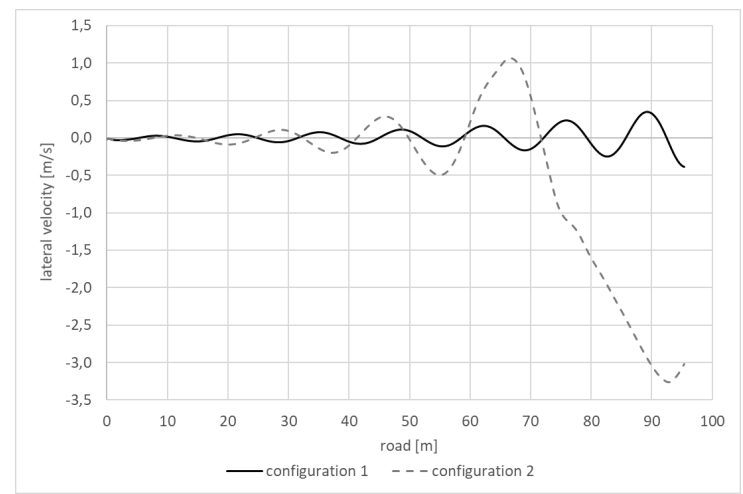

Fig. 5. Lateral velocity versus the covered distance on the flat road

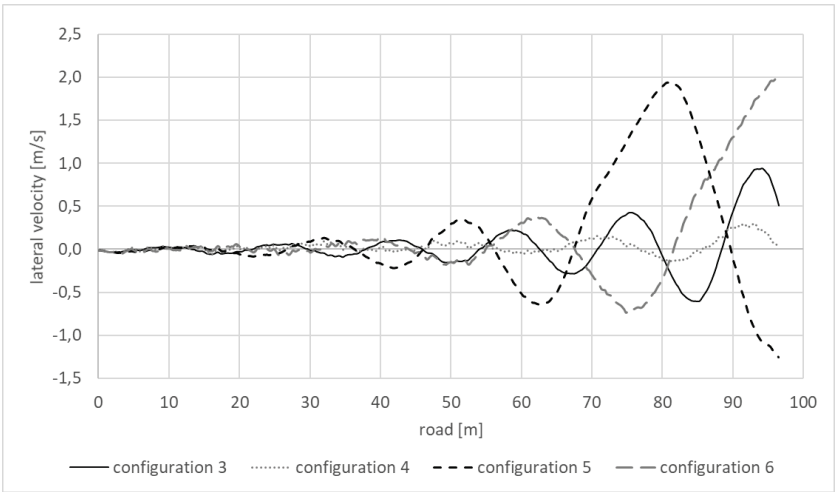

Fig. 6. Lateral velocity versus the covered distance on the randomly uneven road 
In figs. 7 and 8, the lateral acceleration for the discussed configurations of the initial conditions (table 2) has been presented.

As for the motion along the flat road (fig. 7), it is obvious that there occurred the lateral acceleration due to the turning maneuver with the release of a steering wheel. It is also obvious that the amplitude of this acceleration for the flat and icy road was twice as high as for the dry road.

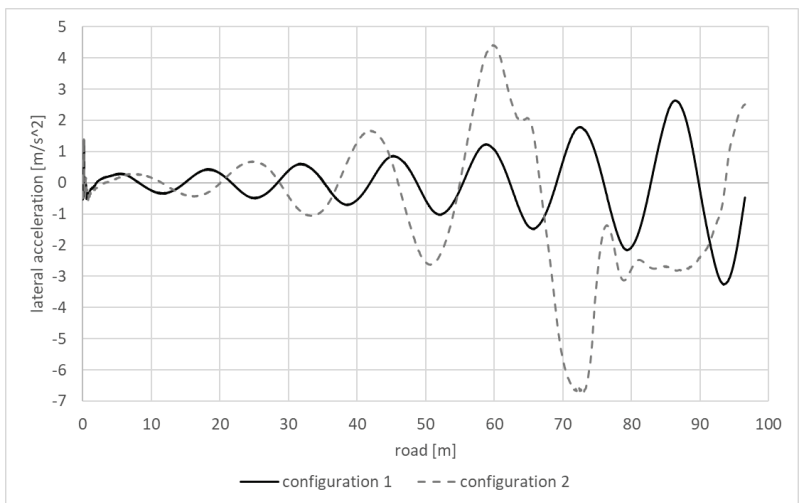

Fig. 7. Lateral acceleration versus the covered distance on the flat road

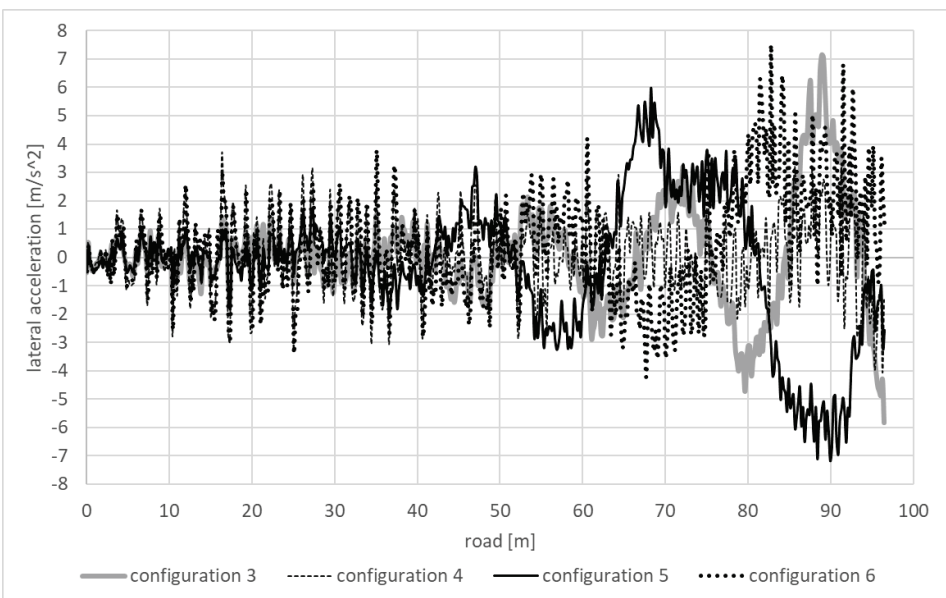

Fig. 8. Lateral acceleration versus the covered distance on the randomly uneven road

The changes in the lateral acceleration (fig. 8) for the motion on the uneven road (configurations 3-6) were more turbulent than in the case of the flat road which shows that the road irregularities may affect the motion of the vehicle as well as the ride comfort of the vehicle's occupants. In fig. 8, the magnitude of this acceleration increased along the covered distance. Since this figure is not so clear, it is justified to explain that the highest amplitudes 
of the acceleration occurred for the configurations 3, 5 and 6 which shows that the motion along the dry and randomly uneven road with the higher amplitudes of the irregularities (intensity 0.9 , configuration 4 ) did not affect the vehicle's motion to such an extent as in case of the three remaining configurations.

In order to complete the presented considerations, the changes in the angular velocity of the simulated vehicle's model relative to its vertical axis passing through the center of the mass, versus the covered distance have been presented in figs. 9 and 10 for the flat and the uneven road surface, respectively.

For the dry surface the results presented in fig. 9 prove the trajectories obtained in fig. 3, where the vehicle's model deviated from the desired course by about $2.5 \mathrm{~m}$. The values of the angular velocity are not very high, but in fig. 9 they show that the vehicle's model performed a rotational motion which may have caused the additional lateral motion presented in figures above.

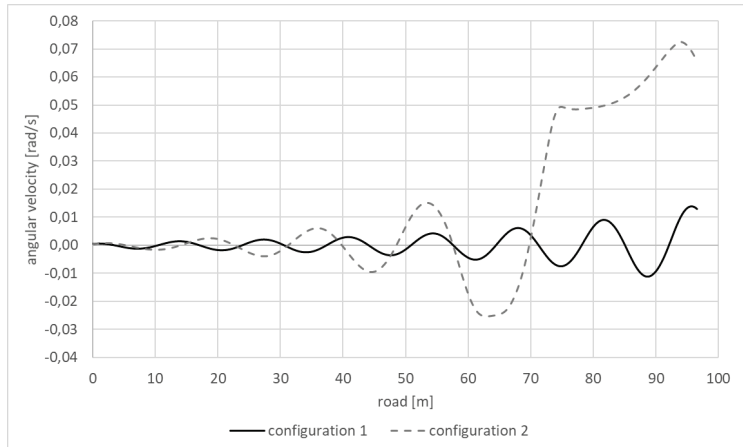

Fig. 9. Angular velocity versus the covered distance on the flat road



Fig. 10. Angular velocity versus the covered distance on the randomly uneven road

As regards the motion on the icy road, it is interesting that the greatest angular velocity (although reaching only about $1.25 \mathrm{rad} / \mathrm{s}$ ) occurred for the motion on the dry road with lower 
amplitudes of irregularities (configuration 4). This indicates that the vehicle's model performed the rotational motion but with less drifting because the lateral acceleration was lowest among the four compared configurations (3-6). Hence, it can be seen that the dry road with little irregularities involved rather rotating than drifting.

It is necessary to remember that this experiment has been conducted with the use of the almost similar profiles for the left and the right wheel, and with the rather moderate-tolow amplitude irregularities.

\section{Conclusions}

From the presented analysis, it can be concluded that the random irregularities may, in some cases, reduce the vehicle's response to the occurring external disturbances, i.e. the road irregularities and the weather conditions. However, it seems important to run analyzes with the use of the almost different road profiles for the left and the right wheel (e.g. $c o r_{r l}=0.2$ ) and the more intensive amplitudes of the road irregularities (e.g. intensity $=1.5$ or 2.0).

On the other hand, it is interesting how such a vehicle's model would respond to the same disturbances of motion but at a different initial speed, e.g. $120 \mathrm{~km} / \mathrm{h}$, which will be the subject of the next paper.

\section{References}

1. Beal C., Brennan S.: Friction detection from stationary steering manoeuvres, Vehicle System Dynamics, Vol. 58, Issue 11, 2020.

2. Castro A. A., Rill G.: Road Vehicle Dynamics: Fundamentals and Modeling with MATLAB $\AA$, CRC Press, 2020.

3. Genta G., Genta A.: Road Vehicle Dynamics: Fundamentals of Modeling and Simulation, World Scientific Publishing Company, 2016.

4. Kisilowski J., Kowalik R.: Numerical Testing of Switch Point Dynamics - A Curved Beam with a Variable Cross-Section, Materials 13(3):701, 2020.

5. Kisilowski J., Zalewski J.: Selected examples of referring the examined stochastic technical stability to the ISO standards, Journal of Theoretical and Applied Mechanics, Vol. 56, No. 1, 2018.

6. Múčka P.: Vibration Dose Value in Passenger Car and Road Roughness, Journal of Transportation Engineering, Part B: Pavements, Vol. 146, Issue 4, 2020.

7. Siergiejczyk M., Rosiński A.: Analysis of the operation process of vehicles equipped with telematic on-board systems, Journal of KONBIN, Vol. 49, Issue 4, 2019.

8. Zalewski J.: Selected Problems of a Motor Vehicle Motion in a Turn After Steering Wheel Release. In: Development of Transport by Telematics, Communications in Computer and Information Science 897, Springer, 2019. 